\title{
Expression of a bovine $\kappa-C N$ cDNA in the mammary gland of transgenic mice utilizing a genomic milk protein gene as an expression cassette
}

\author{
ALFONSO GUTIÉRREZ ${ }^{1}$, HARRY M. MEADE ${ }^{2}$, PAUL DITULLIO ${ }^{2}$, \\ DANIEL POLLOCK ${ }^{2}$, MERRY HARVEY ${ }^{2}$, RAFAEL JIMÉNEZ- \\ FLORES $^{3}$, GARY B. ANDERSON ${ }^{1}$, JAMES D. MURRAY ${ }^{1,4}$ and \\ JUAN F. MEDRANO ${ }^{1 *}$ \\ ${ }^{I}$ Department of Animal Science and ${ }^{4}$ Department of Population Health and Reproduction, University of \\ California, Davis, CA 95616-8521 USA \\ ${ }^{2}$ Genzyme Transgenic Corporation, One Mountain Road, Framingham, MA 01536 USA, and \\ ${ }^{3}$ Department of Dairy Science, California Polytechnic State University, San Luis Obispo, CA 93407, USA
}

Transgenic mice were produced by microinjection of a DNA construct composed of the bovine $\kappa$-casein $(\kappa-\mathrm{CN})$ cDNA under the control of the goat $\beta-\mathrm{CN} \mathrm{5}$ promoter elements and $3^{\prime}$ flanking regions into pronuclear-stage embryos. The gene construct targeted the expression of bovine $\mathrm{K}-\mathrm{CN}$ RNA to the mammary gland and secretion of bovine $\mathrm{k}-\mathrm{CN}$ in the milk. In the three lines studied (BC-7, BC-31 and BC-67) the transgene was stably integrated and propagated as a Mendelian locus. Expression of the bovine protein in lactating mice from the three transgenic lines was demonstrated by northern and western blots. In ten different tissues analysed by northern blotting, expression was confined to the mammary gland of lactating transgenic mice from line $\mathrm{BC}-7$, with low-level expression also observed in the salivary gland of lines $\mathrm{BC}-31$ and $\mathrm{BC}-67$. Transgene expression in the mammary gland paralleled normal casein gene expression during lactation and was not observed in virgin females. The level of bovine $\kappa-C N$ mRNA expression on day 10 of lactation in hemizygous transgenic females in relation to endogenous mRNA of whey acid protein (WAP) gene expression was $14 \%, 69 \%$ and $127 \%$ in lines $\mathrm{BC}-7, \mathrm{BC}-31$ and $\mathrm{BC}-67$, respectively. No association between transgene copy number and expression was observed. The bovine $\mathrm{k}-\mathrm{CN}$ concentration in milk on day 10 of lactation ranged from 0.94 to $3.85 \mathrm{mg}$ of protein per ml of milk. The bovine $\kappa-\mathrm{CN}$ expressed in mouse milk had the same molecular mass and immunoactivity with polyclonal antibodies as did $\kappa-\mathrm{CN}$ from bovine milk. A high degree of variation in the production of bovine $\mathrm{k}-\mathrm{CN}$ within each of the transgenic lines was observed.

Keywords: bovine $\kappa$-casein; transgenic; tissue specificity; mouse milk

\section{Introduction}

The manipulation of milk composition by gene transfer has considerable potential for the improvement of dairy animals, both for production of biomedical proteins and for direct manipulation of milk composition (for reviews see Wall et al., 1992; Yom and Bremel, 1993). Modification of the casein $(\mathrm{CN})$ components to improve the manufacturing properties of milk and the production of

*To whom correspondence should be addressed. cheese can potentially be achieved by genome incorporation of additional casein genes.

Caseins are the major protein component of milk and are stored and secreted in the form of stable calciumphosphate micelles. The micelles are composed of $\alpha_{\mathrm{s} 1^{-}}$, $\alpha_{\mathrm{s} 2^{-}}$, and $\beta-\mathrm{CN}$, which interact with calcium and $\kappa-\mathrm{CN}$ (Waugh, 1971) found predominantly on the surface of the micelle (Schmidt, 1982). The structure and physical stability of the micelle govern many of the complex properties of milk and its industrial uses. The protein that allows the formation of micelles and determines micelle size and function is $\kappa-\mathrm{CN}$. It differs from other caseins in 
that it is soluble over a broad range of calcium ion concentrations and contains a hydrophilic c-terminal region. Kappa-CN is important in preventing micellar aggregation during the undesirable, thermally-induced gelation of milk and in the formation of cheese curd promoted by the enzymatic action of rennet. Milk with smaller casein micelles, and a greater surface concentration of $\kappa-\mathrm{CN}$, is more stable to heat than milk containing large micelles with less $\kappa-\mathrm{CN}$ on the surface (Fox, 1982). Increased expression of $\kappa-\mathrm{CN}$ protein in the mammary gland may reduce micelle size, increase the thermal stability of $\mathrm{CN}$ aggregates, and reduce the degree of coagulation and gelation in various milk products during the sterilization process of fluid milk (Jiménez-Flores and Richardson, 1988; Kang and Richardson, 1985; Wilmut et al., 1990; Clark, 1992; Yom and Bremel, 1993). Decreasing micelle diameter means there is a large micelle surface area to allow the formation of a firmer and more consistent curd. This dense coagulum retains a greater proportion of solids in the curd, resulting in a higher cheese yield (Schaar, 1981, 1984; Marziali and Ng-Kwai-Hang, 1986).

After the initial work of Gordon et al. (1987) showing protein expression from a fusion gene directed to the mammary gland, numerous transgenic mouse models have been generated. Heterologous proteins expressed in mouse milk include sheep $\beta$-lactoglobulin (Simons et al., 1987; Whitelaw et al., 1992), guinea pig $\alpha$-lactalbumin (Maschio et al., 1991), rat $\beta$-CN (Lee et al., 1988, 1989), rat whey acidic protein (WAP) (Bayna and Rosen, 1990), bovine $\alpha_{\mathrm{s} 1}$-casein (Yom et al., 1993), bovine- $\alpha$-lactalbumin (Vilotte et al., 1989; Bleck and Bremel, 1994), and goat B-CN (Persuy et al., 1992; Roberts et al., 1992). The high level of expression $\left(24 \mathrm{mg} \mathrm{ml}^{-1}\right)$ that has been achieved with the goat $\beta-C N$ gene in the lactating mammary gland of transgenic mice (Persuy et al., 1992) supports the goat $\beta-\mathrm{CN}$ gene as a gene of choice for creating mammary expression cassettes for the production of transgenic animals.

In this paper, the mammary tissue-specific expression of a bovine $\kappa-C N$ cDNA (b- $\kappa-C N$ ) utilizing the goat $\beta$ $\mathrm{CN}$ gene as an expression cassette is reported. The tissue specificity and developmental-regulatory expression of the transgene are described at the $\mathrm{mRNA}$ and protein levels in three lines of transgenic mice with different numbers of copies of the transgene.

\section{Materials and methods}

\section{Transgene construction}

The mammary gland-specific expression cassette used to direct expression of bovine $\kappa-\mathrm{CN}$ to the milk of transgenic mice is shown in Fig. 1A. The vector contained a partial к-CN cDNA sequence (815 nucleotides), from nucleotide 35 of exon 1 to nucleotide 849 of the polyadenylation site in exon 5 (Stewart et al., 1984; EMBL accession number $\mathrm{X} 00565$ ), and a poly-A tail of 15 nucleotides (nt). The cDNA encompassed the $\mathrm{\kappa}-\mathrm{CN}$ translation initiation site (ATG), leader peptide, stop codon and untranslated regions of exons 4 and 5. The $\kappa-C N$ cDNA and poly-A tail were fused into exons 2 and 7 of the goat $\beta-C N$ gene (Roberts et al., 1992), with a 6.2-kb $5^{\prime}$ and a 7.1-kb $3^{\prime}$ of flanking regions of goat $\beta-\mathrm{CN}$.

The $\kappa-\mathrm{CN}$ cDNA clone was obtained from a Holstein

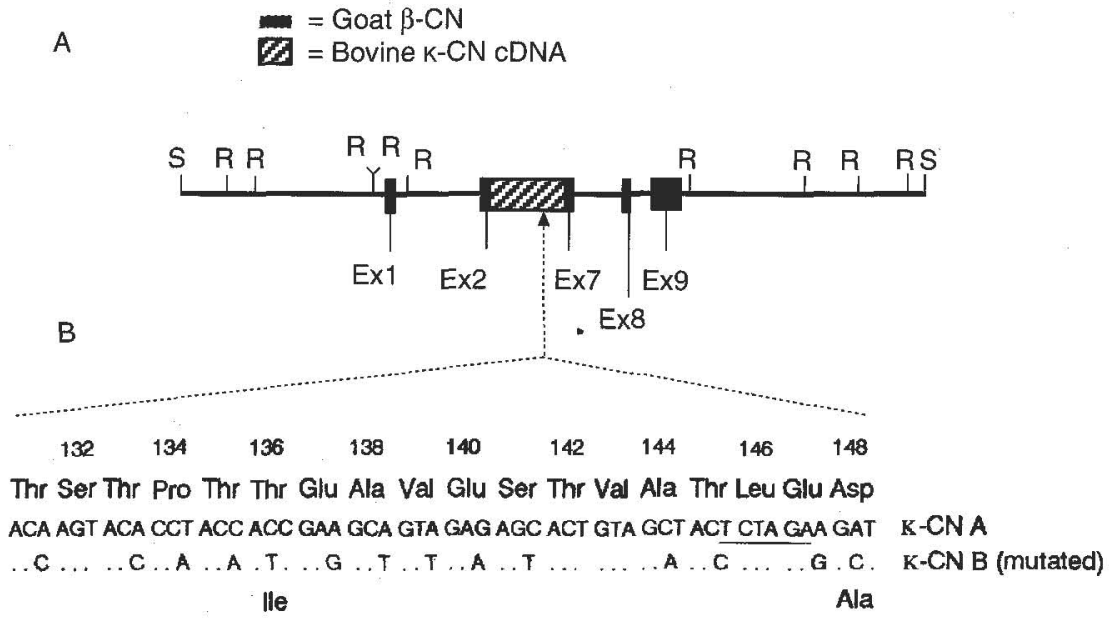

Fig. 1. (A) Structure and restriction map of the goat $\beta-\mathrm{CN}$ bovine $\mathrm{k}-\mathrm{CN}$ transgene. The $14 \mathrm{~kb}$ microinjection fragment contains the entire bovine $\kappa-\mathrm{CN}$ cDNA fused between exons 2 and 7 of the goat $\beta-\mathrm{CN}$ gene. Abbreviations: S, Sal I; R, Eco RI. (B) Detail of the mutagenized region of the $\kappa-C N$ cDNA between amino acids 131 to 148 . Top rows show the amino acid and nucleotide sequence of the $\kappa-C N A$ variant (original clone). Bottom rows show the nucleotides and amino acids changed to create the $\mathrm{k}-\mathrm{CN} \mathrm{B}$ construct. The nucleotides changed in the $\kappa-C N$ B construct correspond to silent mutations and codon alterations of amino acids 136 and 148 . The $X b a \mathrm{I}$ site in the $\kappa-\mathrm{CN} \mathrm{A}$ sequence is underlined. 
cow mammary gland. The clone was identified from a $\lambda$ gt10 library and subcloned into pUC19. Sequence data showed two nucleotide differences between this clone and the published $\mathrm{\kappa}-\mathrm{CN}$ sequence (Stewart et al., 1984). One was a silent nucleotide change, $\mathrm{C}$ to $\mathrm{T}$, in the codon of Ser-33, and the other was an $A$ to $G$ that changed the codon of Ser-155 to Gly. The $\kappa-C N$ cDNA was mutagenized to change the codon corresponding to Thr136 to Ile, and that of Asp-148 to Ala, thus matching the protein sequence of the $\mathrm{k}-\mathrm{CN} \mathrm{B}$ variant form. As shown in Fig. 1B, several other nucleotides in the region between amino acids 131 to 148 were also changed. The $850 \mathrm{nt}$ mutagenized cDNA $\mathrm{\kappa}-\mathrm{CN}$ was cloned from the pUC19 vector as an Xho I fragment and ligated into a goat $\beta-\mathrm{CN}$ vector gbc166 at the $\mathrm{Xho} I$ site, between exon 2 and 7 of the goat $\beta-\mathrm{CN}$ gene (Roberts et al., 1992).

The whole construct used to produce transgenic mice was purified as a $14 \mathrm{~kb}$ Sal I fragment (Fig. 1A). The plasmid was prepared and cut with Sal I and run on a $1 \%$ TAE gel overnight to separate the fragments. The $14 \mathrm{~kb}$ fragment was electroeluted in dialysis tubing and then purified on a $\mathrm{CsCl}$ gradient. The band containing the DNA was removed, dialyzed and recovered by ethanol precipitation and resuspended in TE buffer.

\section{Generation and screening of transgenic mice}

Transgenic mice were generated by microinjection of $1-$ $2 n g \mu I^{-1}$ of construct DNA into the pronuclear-stage mouse embryos obtained from CD1 female mice crossed with C57BL6J males. The microinjected embryos were transferred into pseudopregnant recipient mice. Of the 68 progeny born, 16 transgenic mice were identified by Southern analysis of DNA extracted from tail biopsies. Blots were probed with a radiolabelled $670 \mathrm{bp} \mathrm{Eco} \mathrm{RI/}$ Hin dIII fragment of the bovine $\kappa-\mathrm{CN}$ cDNA. The transgene copy number was determined using slot blots, by comparing the band intensity of the bovine $\kappa-\mathrm{CN}$ gene (obtained from bovine DNA) with that of the mouse $\mathrm{k}-\mathrm{CN}$ transgene on a densitometer (Ultroscan XL, LKB Bromma).

DNA from progeny of founder mice was extracted from tail or toe clips of pups as described by Maga et al. (1994), and the presence of the transgene was assayed by PCR analysis. Primers JK6 (5'-CAA CTA CCA TGG CAC GTC AC-3') and JK7 (5'-CCG AAG GCA GAC AAC TGG-3'), specific for amplification of a $300 \mathrm{bp}$ region of the b-k-CN cDNA, were used. Amplification was carried out in a total volume of $25 \mu l$ of PCR mix containing 1 unit Taq polymerase (Promega), $2.5 \mu l 10 \times$ buffer (Promega), $100 \mu \mathrm{M}$ each dNTP, $0.1 \mu \mathrm{M}$ each primer and $2.5 \mathrm{mM} \mathrm{MgCl}_{2}$. PCR reaction were performed for 30 cycles at $92{ }^{\circ} \mathrm{C}(1 \mathrm{~min}), 60{ }^{\circ} \mathrm{C}(1 \mathrm{~min})$ and $72{ }^{\circ} \mathrm{C}$ $(1 \mathrm{~min})$. In the first PCR cycle denaturation was at $92^{\circ} \mathrm{C}$ for $2 \mathrm{~min}$.

Homozygous animals were produced by mating hemi- zygous transgenic animals. Pups were screened by semiquantitative PCR analysis and homozygosity confirmed by test mating. Semi-quantitative PCR was performed by comparing the amount of DNA amplified in two consecutive PCR cycles. Line BC-7 and BC-67 were run for 19 and 20 cycles and line BC-31 for 20 and 21 cycles. PCR reactions were performed in a volume of $50 \mu \mathrm{l}$ in a mixture containing $50 \mathrm{ng}$ of tail DNA, 2 units Taq polymerase, $5 \mu 110 \times$ buffer, $100 \mu \mathrm{M}$ each dNT?, $0.2 \mu \mathrm{M}$ each primer, $1.5 \mathrm{mM} \mathrm{MgCl}_{2}$ and $1 \mathrm{mg} \mathrm{ml}^{-1}$ gelatin. Amplification conditions were $94{ }^{\circ} \mathrm{C}(1 \mathrm{~min})$, $64{ }^{\circ} \mathrm{C}(1.5 \mathrm{~min})$ and $72{ }^{\circ} \mathrm{C}(2 \mathrm{~min})$. In the first cycle denaturation was at $94{ }^{\circ} \mathrm{C}$ for $3 \mathrm{~min}$.

\section{RNA isolation and northern analysis}

Total RNA was isolated by homogenization of tissues using an acid guanidinium thiocyanate-phenol-chloroform extraction method (Chomczynski and Sacchi, 1987). Northern analysis was performed as described by Maga et al. (1994) on total RNA extracted from mammary gland, kidney, liver, sublingual and submandibular salivary glands, spleen, lung, heart, skeletal muscle, skin, ovary and uterus of day-10 lactating transgenic females. Mammary gland of virgin females and females at day 2 before parturition of days 4,10 and 17 of lactation were also analysed $(\mathrm{n}=3$ females per treatment). Twenty $\mu \mathrm{g}$ of total RNA were separated on MOPS/formaldehyde agarose gels and transferred to a nylon membrane (GeneScreen Plus, DuPont, Boston, MA) in the presence of $10 \times$ SSC. A $670 \mathrm{bp} \mathrm{Eco} \mathrm{RI/HindIII} \mathrm{fragment} \mathrm{of} \mathrm{the} \mathrm{bovine} \kappa-\mathrm{CN}$ cDNA, labelled with $\left[\alpha^{32} \mathrm{P}\right]$ dCTP $\left(3000 \mathrm{Ci} \mathrm{mmol}^{-1}\right.$, Amersham, Arlington Heights, IL) by random priming, was used as probe to detect the b-к-CN mRNA. To detect the expression of endogenous WAP mRNA, a $560 \mathrm{bp}$ Pst $\mathrm{I}$ fragment of the WAP cDNA was used. Hybridization was carried out overnight at $68{ }^{\circ} \mathrm{C}$ in the presence of $0.5 \mathrm{M}$ sodium phosphate buffer and $7 \%$ SDS. Prior validation indicated that under these hybridization conditions that $670 \mathrm{bp}$ of the bovine $\mathrm{k}-\mathrm{CN}$ cDNA did not hybridize to the endogenous mouse $\kappa-\mathrm{CN}$ gene. Filters were washed in $2 \times$ $\mathrm{SSC} / 0.1 \%$ SDS and $0.2 \times \quad \mathrm{SSC} / 0.1 \% \quad \mathrm{SDS}$ at room temperature for $30 \mathrm{~min}$ each. Autoradiography was performed at $-70{ }^{\circ} \mathrm{C}$ overnight using Amersham X-ray film and scanned with a densitometer to obtain a mean absorbance value of signal present. Levels of message were quantified as a percentage of the amount of WAP message present on day 10 of lactation.

\section{Western analysis of transgenic mouse milk proteins}

Milk samples were collected on days 5, 10 and 15 of lactation from transgenic mice. The mother was separated from her pups for at least $3 \mathrm{~h}$ and injected intraperitoneally with $0.2 \mathrm{IU}$ of oxytocin (Sigma, St. Louis, MO) to stimulate milk ejection. The milk was collected by a mechanical suction apparatus with the aid of vacuum into 
$1.5 \mathrm{ml}$ Eppendorf tubes. The milking was continued for each mouse until there was no further milk yield from any nipple. Approximately 1 to $1.5 \mathrm{ml}$ of milk was collected per mouse. Milk was stored at $-70{ }^{\circ} \mathrm{C}$ until analysis.

Milk proteins from mouse milk were separated using SDS-PAGE (Basch et al., 1985). Each milk sample was spun to remove fat, and from the skim milk a volumetric sample was taken and total protein determined by colorimetric assay (Bio-Rad protein assay). The samples were diluted 1:5 ( $\mathrm{vol} / \mathrm{vol})$ with SDS loading buffer, and equal amounts of total protein were loaded into each well for SDS-PAGE. The proteins were then electrophoretically transferred to polyvinylidene difluoride membranes using a semi-dry transfer cell (Bio-Rad Laboratories). After transfer, the membranes were incubated overnight in TPBS (phosphate buffered saline with $0.1 \%$ Tween20), followed by a 40-min incubation with $1: 3000$ (vol/ vol) dilution of primary antibodies (rabbit anti-bovine-к$\mathrm{CN}$ ) in PBS- $0.1 \%$ Tween-20. Blots were washed with TPBS and affinity-purified goat anti-rabbit IgG conjugated to alkaline phosphatase (diluted 1:4000 vol/vol, in TPBS) was applied to the blots. Blots were incubated for 30 min with gentle agitation, with the second antibody and then washed. The $\mathrm{\kappa}-\mathrm{CN}$ band was detected using an alkaline phosphatase colour substrate solution $(10 \mu \mathrm{l}$ hydrogen peroxide, $10 \mathrm{mg}$ of 3,3'-diaminobenzedine (Sigma), and $10 \mathrm{ml}$ PBS).

Quantification from the western blots of bovine $\kappa-\mathrm{CN}$ in mouse milk was done in triplicate using a digital densitometer with the Collage@ Software (Fotodyne, Hartland, WI). Each membrane contained seven mouse milk samples and three controls with different concentrations of bovine $\kappa-\mathrm{CN}\left(100,150\right.$ and $\left.200 \mu \mathrm{g} \mathrm{ml}^{-1}\right)$. After developing the western blots, the images were digitized and a quantitative integration of the intensity and area for each band was performed. A linear standard curve was constructed from the controls and used to assign the $\mu \mathrm{g} \mathrm{ml}^{-1}$ of $\kappa-\mathrm{CN}$ present in each of the mouse milk samples.

\section{Results}

Transgenic mice carrying a DNA construct containing a b$\kappa-\mathrm{CN}$ cDNA with the $5^{\prime}$ and $3^{\prime}$ flanking DNA regions of the goat $\beta-C N$ regulatory expression elements were generated (Fig. 1). In 16 founder transgenic mice identified by Southern blotting, the transgene copy number varied between 1 and 20 . One exceptional male had approximately 100 copies. For this work three lines were studied (BC-7, BC-31 and BC-67) with different copy numbers (Table 1), where the transgene was stably integrated and transmitted as a Mendelian locus.

Northern analysis of ten different tissues collected from female transgenic mice on day 10 of lactation revealed that $\mathrm{b}-\kappa-\mathrm{CN}$ mRNA was expressed specifically in the mammary gland of lactating transgenic mice. Female mice of the lines $\mathrm{BC}-31$ and $\mathrm{BC}-67$, which had the higher level of expression of the transgene in the mammary gland, also showed a very low degree of expression of $\kappa-\mathrm{CN}$ in salivary gland (Fig. 2). Transgene expression was not detected in other tissues tested. Line $\mathrm{BC}-7$ with low b-к-CN expression in the mammary gland did not show transgene expression in any of the other tissues examined. Hybridization with a bovine $\kappa-\mathrm{CN}-$ specific probe yielded a single band larger than bovine $\kappa-$ CN mRNA (1150 vs $900 \mathrm{nt}$ respectively). The size was in agreement with the size of the bovine $\kappa-\mathrm{CN}$ mRNA combined with part of the goat $\beta-\mathrm{CN}$ exons present in the DNA construct (Fig. 3).

The amount of $b-\kappa-C N$ mRNA detected in the mammary gland of day-10 lactating transgenic mice varied considerably from one line to the other (Table 1 , Figs 2, 3 and 4). There was no association between transgene copy number and expression of the transgene. Line $\mathrm{BC}-7$, which had an intermediate copy number (510 ), had the lowest expression level; line BC-31 with one copy expressed approximately $50 \%$ of line BC-67 carrying 20 copies of the transgene. Transgene expression in mammary gland was developmentally regulated in a

Table 1. Characteristics of $\mathrm{b}-\mathrm{k}-\mathrm{CN}$ transgenic mouse lines

\begin{tabular}{lccc}
\hline Line & $\begin{array}{l}\text { Copy } \\
\text { number } \\
(n=5)\end{array}$ & $\begin{array}{l}\text { Expression of } \\
b-\kappa-C N \text { mRNA } \\
(\% \pm S D)(n=3)\end{array}$ & $\begin{array}{l}\text { Bovine- } \kappa-C N \\
\text { in milk } \\
\left(m g m l^{-1}\right) \pm S D\end{array}$ \\
\hline Control & - & - & - \\
BC-31 hemizygous & $\sim 1$ & $69 \pm 15.7$ & $2.6 \pm 1.0$ \\
BC-31 homozygous & & $128 \pm 19.8$ & $3.8 \pm 2.1$ \\
BC-7 hemizygous & $5-10$ & $14 \pm 7.6$ & $0.9 \pm 1.4$ \\
BC-7 homozygous & & $25 \pm 17.6$ & $1.7 \pm 0.8$ \\
BC-67 hemizygous & $\sim 20$ & $127 \pm 19.8$ & $2.9 \pm 0.9$ \\
BC-67 homozygous & & $233 \pm 28.1$ & $3.7 \pm 2.1$ \\
\hline
\end{tabular}

${ }^{a}$ Quantity of b-к-CN mRNA compared with WAP mRNA in the mammary gland of day-10 lactating mice. 


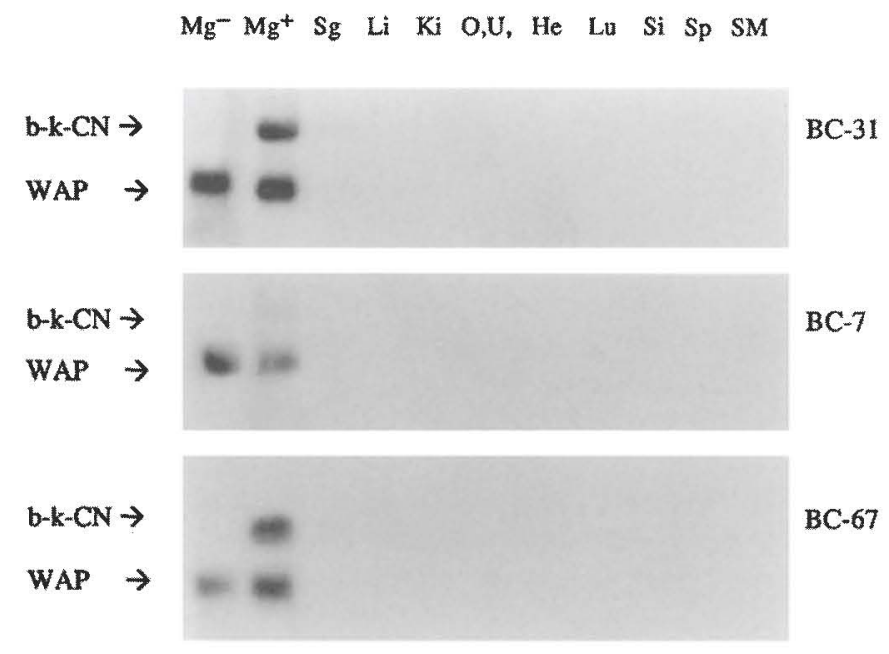

Fig. 2. Tissue specificity of $b-\kappa-C N$ transgene expression. Northern blot analysis of total RNA isolated from day-10 lactating females of lines BC-31, BC-7, BC-67, and control. Filters were probed with ${ }^{32} \mathrm{P}$ with fragments of $\mathrm{b}-\mathrm{k}-\mathrm{CN}$ cDNA and murine WAP cDNA as described in Materials and methods. The tissues were nontransgenic mammary gland $(\mathrm{Mg}-)$, transgenic mammary gland $(\mathrm{Mg}+)$, salivary gland $(\mathrm{Sg})$, liver (Li), kidney (Ki), ovary and uterus $(\mathrm{O}, \mathrm{U})$, heart $(\mathrm{He})$, lung $(\mathrm{Lu})$, skin $(\mathrm{Si})$, spleen $(\mathrm{Sp})$ and skeletal muscle (SM). The sizes of WAP and b- $\kappa-\mathrm{CN}$ mRNAs were about 600 and 1150 nucleotides, respectively.

similar manner to the expression of the endogenous mouse WAP gene (Fig. 4). When comparing transgene expression with the endogenous WAP gene expression, the highest expression of $\mathrm{b}-\kappa-\mathrm{CN}$ mRNA (line BC-67) was approximately $120 \%$ that of the endogenous WAP mRNA, while line BC-31 exhibited b-k-CN mRNA expression at approximately $77 \%$ of the endogenous WAP mRNA. Transgene expression in homozygous mice was approximately double that observed in hemizygous mice.

The developmental regulation of $\mathrm{b}-\mathrm{k}-\mathrm{CN}$ expression was similar in the three transgenic lines (Figs 3 and 4). The principal difference was that lines BC-31 and BC-67 expressed the transgene at low levels ( $2-3 \%$ of WAP) 2 days prepartum, while BC-7 did not (Fig. 4). The expression increased from day 4 to day 10 of lactation and then decreased by day 17 (Figs 3 and 4). Bovine $\kappa-$ CN mRNA expression was not observed in mammary gland extracts from virgin transgenic mice (Fig. 3).

The total protein was not significantly different at day 5 and 15 of lactation, but at day 10 line BC-7 had 19\% more protein that lines BC-31 and BC-67 ( $p<0.05$, oneway ANOVA). Protein was measured to normalize the amount loaded in the gels for each sample (range: 40 to $60 \mathrm{mg} \mathrm{ml}^{-1}$ ). Expression of b-к-CN was detected in all the transgenic lines, and no cross reaction was detected in the control mice. There seemed to be little association between the amount of mRNA in the cells (Fig. 4) and the total amount of b- $\mathrm{k}-\mathrm{CN}$ expressed in the different lines of mice (Fig. 5). The three lines showed increased levels of b-к-CN at day 10 of lactation, when levels of mRNA were proportionally higher; however, the amount of protein expressed among the lines did not reflect the higher relative abundance of mRNA in lines BC-31 and $\mathrm{BC}-67$. Furthermore, at day 15 of lactation there was a slightly higher level of $\kappa-\mathrm{CN}$ in line $\mathrm{BC}-7$ than in the other two lines.

To study further the differences in expression levels of b-k-CN between hemizygous and homozygous mice, the western blots were repeated in a separate experiment using milk from the mice born two generations after those of the first experiment. Ten first parity female mice per line were sampled at day 10 of lactation (five hemizygous and five homozygous). The average expres-

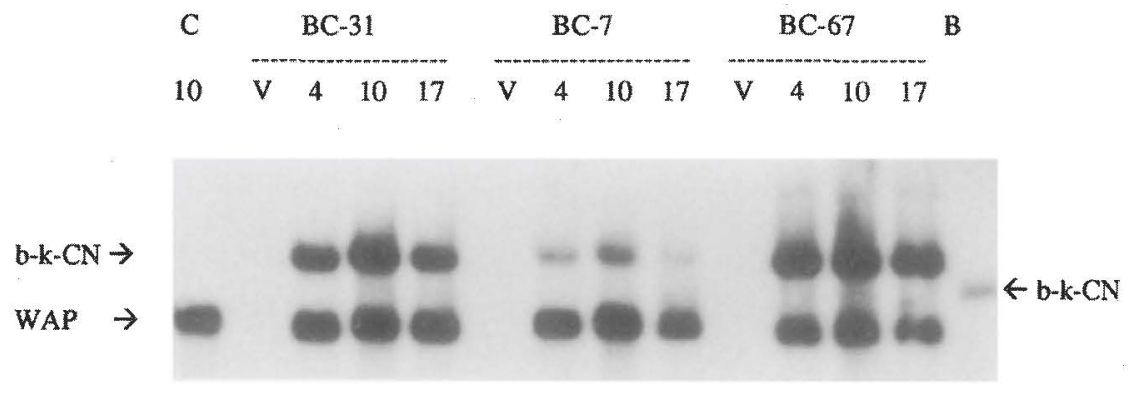

Fig. 3. Representation of developmental regulation of b-к-CN expression in the mammary gland of lines $\mathrm{BC}-31, \mathrm{BC}-7$ and $\mathrm{BC}-67$ transgenic mice compared with endogenous mWAP gene expression. Northern blot analysis of one of the three animals analyzed per time point with ${ }^{32} \mathrm{P}$ b-k-CN cDNA and WAP cDNA as probes. B, bovine mammary gland $(5 \mu \mathrm{g})$; $\mathrm{C}$, nontransgenic day-10 lactating female; V, virgin transgenic mice; mammary gland from transgenic mice at 4,10 and 17 days of lactation. The sizes of WAP, b-к-CN expressed by transgenic mice and endogenous b-к-CN (expressed by bovine mammary gland mRNAs were about 600, 900 and 1150 nucleotides, respectively. 


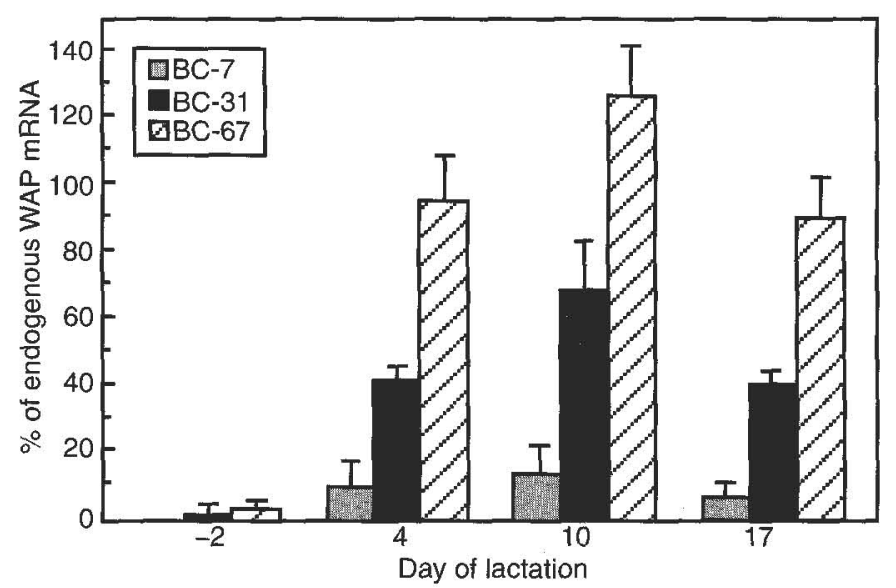

Fig. 4. Developmental expression of b- $-\mathrm{CN} m \mathrm{~m} N A$ during lactation. Relative level of b-k-CN mRNA compared with WAP mRNA ( \pm SD) of line $\mathrm{BC}-7, \mathrm{BC}-31$ and $\mathrm{BC}-67$ at day 10 of lactation. Three animals were analysed per line and time point.

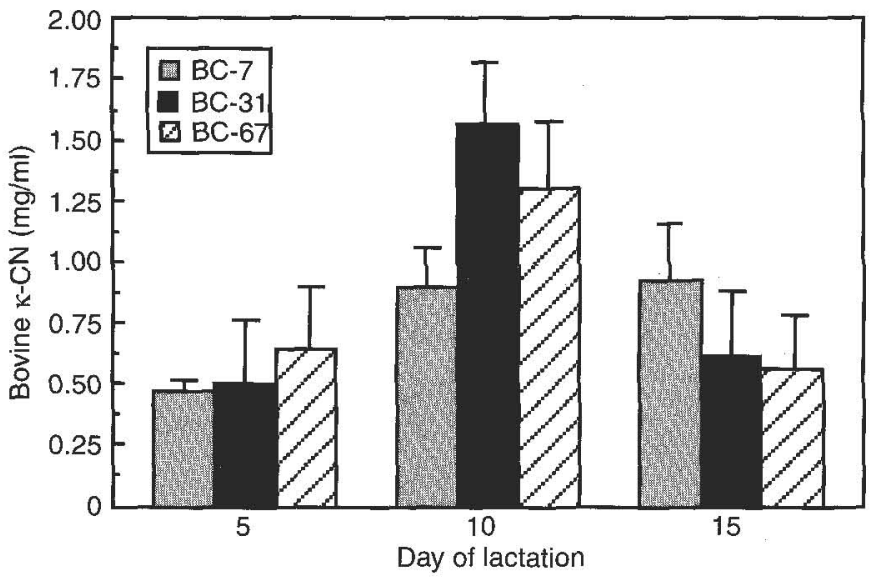

Fig. 5. Developmental expression of b-k-CN during lactation. Quantification of the protein was realized by western blots analysing samples of three animals per line and time point. Mean b-k-CN concentrations ( \pm SD) are shown at day 5, 10 and 15 of lactation for each transgenic line.

sion of hemizygous mice was $0,1.6$ and 2.2 times higher than in the first experiment in lines $\mathrm{BC}-7, \mathrm{BC}-31$ and $\mathrm{BC}-67$, respectively. Due to the high degree of variability in the expression of b-к-CN between animals of the same transgenic line (Fig. 6), the differences were not statistically significant, with the exception of line $\mathrm{BC}-67$ $(p<0.05, t$-test). The mean values of b-к-CN expression were consistently higher in homozygous than hemizygous mice in all the lines (Fig. 6), although the differences were also not significant.

The presence of b-к-CN expressed in mouse milk did not appear to affect the physiology of the mammary gland, and the growth of the pups was observed to be normal (data not shown).

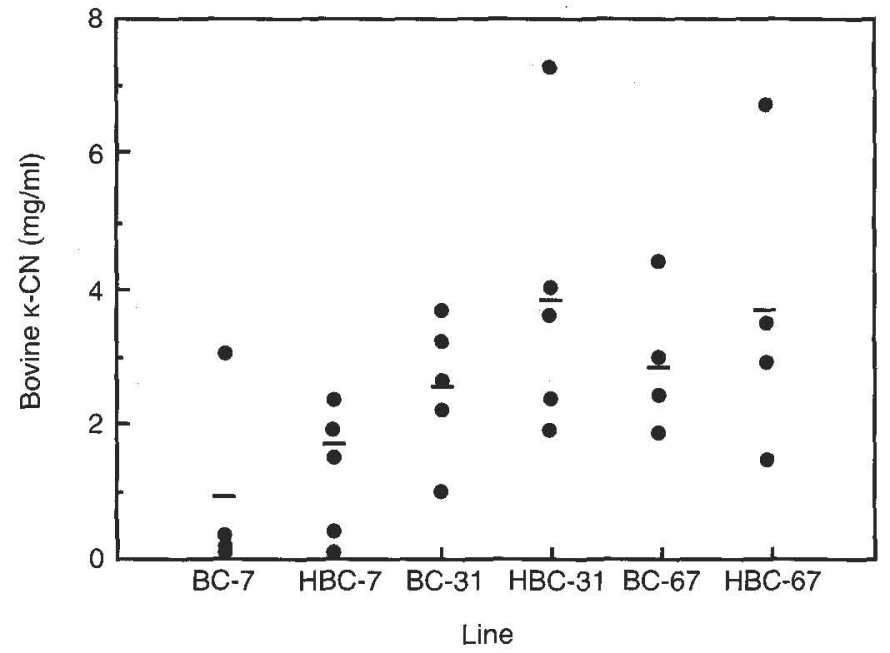

Fig. 6. Expression of bovine $\mathrm{k}-\mathrm{CN}$ on day 10 of lactation (separate experimental data from that shown in Fig. 5, see Results). Each point represents the level of bovine $\mathrm{k}-\mathrm{CN}$ present in the milk samples from individual hemizygous (BC) and homozygous (HBC) mice from each transgenic line. The horizontal line represents the mean protein expression in each line.

\section{Discussion}

Transgenic mice were produced carrying the $b-\kappa-C N$ cDNA under the control of the goat $\beta-C N$ regulatory elements and this construct was tested for production of heterologous proteins in the milk of transgenic mice as a model for studying the production of increased amounts of $\mathrm{b}-\kappa-\mathrm{CN}$ in transgenic cows. To test the tissue specificity of expression of a transgene and to quantify possible alterations of the milk quality, it is practical first to introduce the construct into cheaper and easier-to-produce transgenic mice.

Having in mind future experiments for the production of transgenic cattle, the construct developed was made to express a $\mathrm{\kappa}-\mathrm{CN} \mathrm{B}$ variant protein, the least frequent variant in Holstein dairy cattle (Van Eenennaam and Medrano, 1991). Since the majority of Holstein embryos are of A type, the presence of this infrequent variant could often be used as a marker for detection of the casein protein produced by a transgene. The silent mutations in the construct (Fig. 1B) were also introduced to be able to detect unequivocally the presence of transgene and to differentiate the transgene mRNA expression from the endogenous bovine $\mathrm{K}-\mathrm{CN}$ mRNA in future experiments with cattle.

The expression of cDNA-based foreign gene constructs in milk of transgenic animals has shown considerable variation when different promoters were used (reviewed by Yom et al., 1993). The presence of introns is essential in most cases for the transgene to be expressed (Whitelaw et al., 1991). With the goat $\beta-C N$ construct used in this study, the b-к-CN cDNA expression was 
relatively high and efficiently regulated in the three transgenic lines. The presence of three goat $\beta-\mathrm{CN}$ introns seems to have fulfilled the role of modulating the regulated expression of the $b-\kappa-C N$ cDNA. Stringent tissue specificity and developmental programming of $\mathrm{CN}$ expression were observed. Similar results were reported for expression of the human cystic fibrosis transmembrane conductance regulator cDNA using a similar expression cassette, a $4.2-\mathrm{kb} 5^{\prime}$ and a $5.3-\mathrm{kb} 3^{\prime}$ flanking sequences to goat $\beta-\mathrm{CN}$ exons (DiTullio et al., 1992). High-level expression of the goat $\beta-\mathrm{CN}$ gene in mice under its own regulatory sequences, using $3-\mathrm{kb} 5^{\prime}$ and 6$\mathrm{kb} 3^{\prime}$ flanking $\beta-\mathrm{CN}$ regions (Persuy et al., 1992) or 4.2$\mathrm{kb} 5^{\prime}$ and 5.3-kb 3' flanking sequences (Roberts et al., 1992) has been reported. In contrast, expression was low in transgenic mice with a rat $\beta-\mathrm{CN}$ genomic transgene composed of 3.5-kb 5' and 3-kb 3' flanking regions (Lee et al., 1988, 1989) and in transgenic rabbits with a chimaeric interleukin-2 gene driven by a $2-\mathrm{kb} 5^{\prime}$ flanking region of the rabbit $\beta-C N$ (Bühler et al., 1990). Some cis-acting elements essential for $\beta-\mathrm{CN}$ gene expression could be absent in the shortened $5^{\prime}$ and/or 3' flanking regions of rat and rabbit $\beta-C N$ construct used in the above reports; also possible is that negative cis-acting elements in the regions of rat and rabbit $\beta-\mathrm{CN}$ are absent in the goat construct.

Transgene expression was largely confined to the mammary gland of lactating transgenic mice. Only a small amount of b-к-CN mRNA was detected in the salivary gland. Using the goat $\beta-\mathrm{CN}$, Persuy et al. (1992) did not detect any transcripts in the salivary gland of one founder mouse tested. The ectopic expression observed in the salivary gland of two of the three lines tested here may be explained by the common structural characteristics of the mammary and salivary glands (Whitelaw et al., 1992). Ectopic expression in the salivary gland has been reported in various transgenic lines using mouse WAP, ovine $\beta$-lactoglobulin, or bovine $\alpha_{s 1}-\mathrm{CN}$ mammary gland-specific promoters (Pittius et al., 1988; Whitelaw et al., 1992; Maga et al., 1994).

The level of transgene mRNA expression was not associated with transgene copy number. This is a common phenomenon generally attributed to influences of the chromosomal sequences flanking the different sites of integration (Overbeek, 1994). Alternatively, when multiple copies are located in the genome, elements in copies located upstream may influence the activity of promoters located downstream (Bieberich et al., 1986; Palmiter and Brinster, 1986). However, homozygous females from the three lines expressed approximately twice the level of hemizygous animals at the mRNA level, which is the same result reported for two lines hemizygous and homozygous for a $\alpha_{s 1}$-CN-lysozyme transgene (Maga et al., 1994). These results could be expected for alleles with codominant expression and suggest that the availability of trans-acting factors in the mammary gland was not limiting. The results further support the concept that chromatin structure or cis-acting sequences affect the level of expression of transgenes within an insertional array, thus leading to copy numberindependent expression.

The lack of association between the relative abundance of $\mathrm{b}-\mathrm{\kappa}-\mathrm{CN}$ mRNA and the actual concentration of protein in the milk may have been caused by several species of mRNA being produced but only one being translated, or due to factors affecting the regulation of milk protein at the post-transcriptional, translational or post-translational levels in addition to transcription of the message (reviewed by Burgoyne and Wilde, 1994). Post-transcriptional regulation of mRNA stability of milk proteins genes has been reported in mammary cell cultures, where the casein mRNA half-life was increased by prolactin, glucocorticoid and cell substratum (Eisenstein and Rosen, 1988). Translational control of mammary protein synthesis has been reported in the rabbit (Devinoy et al., 1978), where high levels of induced casein mRNA were not accompanied by similar stimulation of casein synthesis. Devinoy et al. (1978) suggested that this phenomenon may reflect that the availability of translational machinery, such as aminoacyl-tRNA synthetases, is limiting milk protein synthesis. Post-translational regulation of milk production also has been observed by intracellular turnover of newly-synthesized milk constituents (Wilde et al., 1991). Although transcriptional control is an important contributor to the regulation of endogenous milk protein production, post-transcriptional events may have an important function in the regulation of expression of heterologous proteins in the milk of transgenic animals.

The transgenic lines showed a high variation in b-k-CN protein levels among animals within the same line. Variation within transgenic lines in the expression of mammary-specific DNA constructs was reported for transgenic mice expressing bovine $\alpha$-lactalbumin (Bleck and Bremel, 1994), and human lactoferrin with regulatory sequences from the bovine $\alpha_{\mathrm{s1}}-\mathrm{CN}$ gene (Platenburg et al., 1994). Bleck and Bremel (1994) suggested that the variations were due to the genetic expression characteristic of the $\alpha$-lactalbumin transgene, and Platenburg et al. (1994) suggested that the differences could be due to the health of the mammary gland at the time of milking or by differing conditions during drawing of the milk that resulted in leakage of varying amounts of interstitial fluid into the milk. Characteristics of the goat $\beta-\mathrm{CN}$ bovine $\kappa-$ $\mathrm{CN}$ cDNA transgene construct could be the cause of differences at the gene expression level. Conversely, the differences observed may effectively reflect the 'normal' variation associated with the expression of transgenes in the mammary gland in animals of a heterogeneous genetic background. As expected in all milk-producing 
animals, variation in the relative levels of the endogenous caseins from individual mice has been reported (Stevenson and Leaver, 1994), and this, together with the variability produced during milking, may also account for the high intra-line variation observed in this study.

If the $\mathrm{k}-\mathrm{CN}$ content of bovine milk were increased to similar concentrations as observed in these transgenic mice $\left(0.9-3.8 \mathrm{mg} \mathrm{ml}^{-1}\right)$, the percentage of $\kappa-\mathrm{CN}$ relative to total caseins could be increased from an average $10 \%$ ( $3 \mathrm{mg} \mathrm{ml}^{-1}$; Yom and Bremel, 1993) to $13-22 \%$. This increment may be sufficient to produce a significant reduction ( 22 to $40 \%$ ) in the average size of the micelle (Donnelly et al., 1984; Dalgleish et al., 1989). Such a reduction, although still within the normal limits of the distribution of micelles sizes, could directly affect the physical properties of milk (e.g., curd gel strength).

Substantial amounts of $\mathrm{b}-\mathrm{k}-\mathrm{CN}$ were produced from a single transgenic locus (line $\mathrm{BC}-31$ ) by gene insertion, using the regulatory elements from the goat $\beta-\mathrm{CN}$ gene. These results confirm that the protein composition of milk can be successfully manipulated without any observed adverse consequences and suggest this gene construct may be useful to target the expression of bovine $\mathrm{k}-\mathrm{CN}$ to the lactating mammary gland of transgenic cattle in order to increase $\mathrm{k}-\mathrm{CN}$ content relative to the other caseins. Preliminary comparative studies of milk from transgenic mice overexpressing $\mathrm{b}-\kappa-\mathrm{CN}$ and wild-type do not show any effect on the time of rennet coagulation, but there is an association with overexpression of b-k-CN and reduction of micelle size and production of a stronger curd in rennet-induced milk. These physical modifications in the milk properties are now being explored in detail.

\section{Acknowledgements}

This research was supported by a grant from the California Dairy Foods Research Center. Dr Alfonso Gutiérrez was supported by a postdoctoral fellowship from Spanish Ministerio de Educación y Ciencia. We thank Alice Moyer for the care of the transgenic lines and Dr Elizabeth Maga for her technical suggestions and comments on the manuscript.

\section{References}

Basch, J.J., Douglas, F.W., Procino, L.G., Holsinger, V.H. and Farrell, H.M. Jr. (1985) Quantitation of caseins and whey proteins of processed milks and whey protein concentrates, application of gel electrophoresis, and comparison with Harland-Ashworth procedure. J. Dairy Sci. 68, 23-31.

Bayna, E.M. and Rosen, J.M. (1990) Tissue-specific, high level expression of the rat whey acidic protein gene in transgenic mice. Nucl. Acids Res. 18, 2977-85.

Bieberich, C., Scangos, G., Tanaka, K. and Jay, G. (1986)
Regulated expression of a murine class I gene in transgenic mice. Mol. Cell. Biol. 6, 1339-42.

Bleck, G.T. and Bremel, R.D. (1994) Variation in expression of a bovine $\alpha$-lactalbumin transgene in milk of transgenic mice. J. Dairy Sci. 77, 1897-904.

Bühler, Th.A., Bruyère, Th., Went, D.F., Stranzinger, G. and Bürki, K. (1990) Rabbit $\beta$-casein promoter directs secretion of human interleukin-2 into the milk of transgenic rabbits. Bio/ Technology 8, 140-3.

Burgoyne, R.D. and Wilde, C.J. (1994) Control of secretory function in mammary epithelial cells. Cell Signalling 6, 60716.

Chomczynski, P. and Sacchi, N. (1987) Single step method of RNA isolation by acid guanidinium thiocyanate phenol chloroform extraction. Anal. Biochem. 162, 156-9.

Clark, A.J. (1992) Prospects for the genetic engineering of milk. J. Cell Biochem. 49, 121-7.

Dalgleish, D.G., Horne, D.S. and Law, A.J.R. (1989) Size-related differences in bovine casein micelles. Biochim. Biophys. Acta 991, 383-7.

Devinoy, E., Houdebine, L.M. and Delouis, C. (1978) Role of prolactin and glucocorticoids in the expression of casein genes in rabbit mammary gland organ culture, quantification of casein mRNA. Biochim. Biophys. Acta 517, 360-6.

DiTullio, P., Cheng, S.H., Marshall, J., Gregory, R.J., Ebert, K.M., Meade, H.M. and Smith, A.E. (1992) Production of cystic fibrosis transmembrane conductance regulator in the milk of transgenic mice. Bio/Technology 10, 74-7.

Donnelly, W.J., McNeill, G.P., Buchheim, W. and McGann, T.C.A. (1984) A comprehensive study of the relationship between size and protein composition in natural bovine casein micelles. Biochim. Biophys. Acta 789, 135-43.

Eisenstein, R.S. and Rosen, J.M. (1988) Both cell substratum regulation and hormonal regulation of milk protein gene expression are exerted primarily at the posttranscriptional level. Mol. Cell. Biol. 8, 3183-7.

Fox, P.F. (1982) Heat-induced coagulation of milk. In Fox, P.F. ed., Developments in Dairy Chemistry, Vol. 1, pp. 189-223. New York: Applied Sci. Pub.

Gordon, K., Lee, E., Vitale, J.A., Smith, A.E., Westphal, H. and Henninghausen, L. (1987) Production of human plasminogen activator in transgenic mouse milk. Bio/Technology 5, 1183-7.

Jiménez-Flores, R. and Richardson, T. (1988) Genetic engineering of the caseins to modify the behavior of milk during processing: a review. J. Dairy Sci. 71, 2640-54.

Kang, Y. and Richardson, T. (1985) Genetic engineering of caseins. Food Technology 39, 89-94.

Lee, K.F., Atiee, S.H. and Rosen, I.M. (1989) Differential regulation of rat $\beta$-casein chloramphenicol acetyltransferase fusion gene expression in transgenic mice. Mol. Cell Biol. 9, 560-5.

Lee, K.F., Demayo, F.J., Atiee, S.H. and Rosen, J.M. (1988) Tissuespecific expression of the rat $\beta$-casein gene in transgenic mice. Nucl. Acids Res. 16, 1027-41.

Maga, E.A., Anderson, G.B., Huang, M.C. and Murray, J.D. (1994) Expression of human lysozyme mRNA in the mammary gland of transgenic mice. Transgenic Res. 3, 36-42.

Marziali, A.S. and Ng-Kwai-Hang, K.F. (1986) Effect of milk composition and genetic polymorphism on coagulating properties of milk. J. Dairy Sci. 69, 1793-8. 
Maschio, A., Brickell, M., Dioussis, D., Mellor, A., Katz, D. and Craig, R.K. (1991) Transgenic mice carrying the guinea-pig $\alpha$-lactalbumin gene transcribe milk protein genes in their sebaceous glands during lactation. Biochem. J. 275, 459-67.

Overbeek, P.A. (1994) Factors affecting transgenic animal production. In Pinkert, C.A. ed., Transgenic Animal Technology: a Laboratory Handbook, pp. 69-114. London: Academic Press, Inc.

Palmiter, R.D. and Brinster, R.L. (1986) Germ-line transformation of mice. Ann. Rev. Genet. 20, 465-99.

Persuy, M-A., Stinnakre, M-G., Printz, C., Mahe, M-F. and Mercier, J-C. (1992) High expression of the caprine $\beta-\mathrm{CN}$ gene in transgenic mice. Eur. J. Biochem. 205, 887-93.

Pittius, C.W., Hennighausen, L., Lee, E., Westphal, H., Nicols, E., Vitale, J. and Gordon, K. (1988) A milk protein gene promoter directs the expression of human tissue plasminogen activator cDNA to the mammary gland in transgenic mice. Proc. Natl. Acad. Sci. USA 85, 5874-8.

Platenburg, G.J., Kootwijk, E.P.A., Kooiman, P.M., Woloshuk, S.L., Nuijens, J.H., Krimpenfort, P.J.A., Pieper, F.R., Boer, H.A. and Strijker, R. (1994) Expression of human lactoferrin in milk of transgenic mice. Transgenic Res. 3, 99-108.

Roberts, B., DiTullio, P., Vitale, J., Hegir, K. and Gordon, K. (1992) Cloning of the goat $\beta$-casein-encoding gene and expression in transgenic mice. Gene 121, 255-62.

Schaar, J. (1981) Casein stability and cheesemaking. Properties of milk: effects of handling, mastitis and genetic variation. Report 52. Uppsala, Sweden: Swedish University of Agricultural Science.

Schaar, J. (1984) Effect of $\kappa$-casein genetic variants and lactation number on the renneting properties of individual milks. $J$. Dairy Res. 51, 397-406.

Schmidt, D.G. (1982) Association of caseins and casein micelle structure. In Fox, P.F. ed., Developments in Dairy Chemistry, Vol. 1, pp. 61-82. New York: Applied Sci. Pub.

Simons, J.P., McClenaghan, M. and Clark, A.J. (1987) Alteration of the quality of milk by expression of sheep $\beta$-lactoglobulin in transgenic mice. Nature 328, 530-2.

Stevenson, E.M. and Leaver, J. (1994) Chromatographic separation of the proteins of mouse milk. Int. Dairy J. 4, 205-20.

Stewart, A.F., Willis, I.M. and Mackinlay, A.G. (1984) Nucleotide sequence of bovine $\alpha_{s 1-}$ and $\kappa$-casein cDNAs. Nucl. Acid Res. 12, 3895-907.

Van Eenennaam, A.L. and Medrano, J.F. (1991) Differences in allelic protein expression in the milk of heterozyous $\mathrm{k}$-casein cows. J. Dairy Sci. 74, 1491-6.

Vilotte, J.L., Solulier, S., Stinnakre, M.G., Massoud, M. and Mercier, J.C. (1989) Efficient tissue specific expression of bovine $\alpha$-lactalbumin in transgenic mice. Eur. J. Biochem. 186, 43-8.

Wall, R.J., Hawk, H.W. and Nel, N. (1992) Making transgenic livestock: genetic engineering on a large scale. J. Cell. Biochem. 46, 113-20.

Waugh, D.F. (1971) Formation and structure of casein micelles. In Mckenzce, H.A. ed., Milk Proteins, Chemistry and Molecular Biology, pp. 3-85. New York: Academic Press.

Whitelaw, C.B.A., Archibald, A.L., Harris, S., McClenaghan, M., Simons, J.P. and Clark, A.J. (1991) Targeting expression to the mammary gland: intronic sequences can enhance the efficiency of gene expression in transgenic mice. Transgenic Res. 1, 3-13.

Whitelaw, C.B.A., Harris, S., McClenaghan, M., Simons, J.P. and Clark, A.J. (1992) Position-independent expression of ovine beta-lactoglobulin gene in transgenic mice. Biochem. J. 286, $31-9$.

Wilde, C.J., Kerr, M.A. and Calver, D.T. (1991) Intracellular degradation of newly synthesized casein in perfused rat mammary gland, Exp. Physiol. 76, 533-7.

Wilmut, I., Archibald, A.L., Harris, S., McClenaghan, M., Simons, J.P., Whitelaw, C.B.A. and Clark, A.J. (1990) Modification of milk composition. J. Reprod. Fert., Suppl. 41, 135-46.

Yom, H-G. and Bremel, R.D. (1993) Genetic engineering of milk composition: modification of milk components in lactating transgenic animals. Am. J. Clin. Nutr. 8(suppl), 299s-306s.

Yom, H-G., Bremel, R.D. and First, N.L. (1993) Mouse mammary tumor virus promoter directs high-level expression of bovine $\alpha_{\mathrm{s} 1}$ casein in milk of transgenic heterozygous and homocygous mice. Animal Biotechnology 4, 89-107. 